\title{
Cultivar and planting season affect lettuce performance in a tropical organic production system ${ }^{1,2}$
}

\author{
Bryan Brunner ${ }^{3 *}$, Linda Wessel-Beaver ${ }^{4}$ and Luisa Flores ${ }^{5}$
}

J. Agric. Univ. P.R. 102 (1-2):39-52 (2018)

\begin{abstract}
Lettuce is a cool season crop typically grown at high altitudes or during the winter months in tropical climates, but is an important vegetable with potential for increased local production in Puerto Rico. To evaluate year round production potential, eleven lettuce cultivars were grown organically in Lajas under eight environments: winter, spring, summer and fall seasons in 2011 and 2012. All cultivars flowered later in the winter than in other seasons. There was a trend for flowering to be earliest in summer, but in many cultivars bolting occurred equally early in spring or fall. For most cultivars the greatest head weight and harvest yield was observed in the winter or spring season. Fall plantings generally resulted in plants with the smallest heads and lowest yields while summer plantings were intermediate in head weight and yield. 'Queensland' was the highest yielder in every season, yielding more than twice the average of all the genotypes in the summer and fall seasons, making it a valuable cultivar for year round production in the tropics. 'Bergam's Green', 'Jericho' and 'Parris Island' also performed fairly well throughout the year. 'Black Seeded Simpson', a locally popular cultivar, performed poorly.
\end{abstract}

Key words: lettuce, Lactuca sativa, organic production, cultivar trial, tropics

\section{RESUMEN}

El cultivar y época de siembra afectan el desempeño de la lechuga en un sistema tropical de producción orgánica

La lechuga es un cultivo de época fresca que típicamente se cultiva en altitud elevada o durante los meses de invierno en climas tropicales, pero es una hortaliza con gran potencial de desarrollo en la producción local en Puerto Rico. Para evaluar el potencial de producción a través del

${ }^{1}$ Manuscript submitted to Editorial Board 13 September 2018.

${ }^{2}$ We appreciate the assistance of undergraduate student Yehokhanan Lugo, graduate student Ricardo Rodriguez, and Research Assistant Juan Toro with field work, and of Consuelo Estevez at the UPR Plant Disease Clinic with pathogen identification.

${ }^{3}$ Researcher, Agricultural Experiment Station, HC-02 Box 11656, Lajas, PR 00667. *Corresponding author. Email: bryan.brunner1@upr.edu

${ }^{4}$ Professor, Department of Agroenvironmental Sciences, University of Puerto Rico, Mayagüez Campus.

${ }^{5}$ Research Associate, Agricultural Experiment Station, HC-02 Box 11656, Lajas, PR 00667. 
año, se sembraron once cultivares bajo manejo orgánico en Lajas bajo ocho ambientes: las épocas de invierno, primavera, verano y otoño en 2011 y 2012. Todos los cultivares florecieron más tarde en el invierno que en otras épocas. Hubo una tendencia para una florecida más temprana en el verano, pero muchos cultivares florecieron igualmente temprano en primavera u otoño. El mayor peso de cabeza y rendimiento se observó en el invierno o primavera para la mayoría de los cultivares. Las siembras de otoño típicamente resultaron en plantas con las cabezas más pequeñas y los rendimientos más bajos, mientras las siembras de verano fueron intermedias para peso de cabeza y rendimiento. 'Queensland' fue el cultivar de mayor rendimiento en todas las épocas, y su rendimiento fue más de dos veces el promedio de todos los genotipos en las épocas de verano y otoño, por lo tanto, es un cultivar valioso para producción todo el año en el trópico. 'Bergam's Green', 'Jericho' y 'Parris Island' también tuvieron buen rendimiento a través del año. 'Black Seeded Simpson', un cultivar comúnmente sembrado en Puerto Rico, tuvo un pobre desempeño.

Palabras clave: lechuga, Lactuca sativa, producción orgánica, prueba de cultivares, trópico

\section{INTRODUCTION}

Approximately 9,090 tons of lettuce (Lactuca sativa) is consumed annually in Puerto Rico, including 609 t of organic lettuce, but only about $100 \mathrm{t}$ or $1.1 \%$ is produced locally (U.S. Census Bureau, 2013; P.R. Department of Agriculture, 2015; FAO, 2015). Distance from farm to consumer, volatile energy costs, and climate change are among several factors that can precipitate large price increases for highly perishable imported vegetables like lettuce. Furthermore, while lettuce is the fifth largest vegetable crop in Puerto Rico, with a value of $\$ 2.2$ million in 2013 , local farmers could be taking a larger share of the $\$ 11.3$ million imported lettuce market (U.S. Census Bureau, 2013; P.R. Department of Agriculture, 2015).

Lettuce is a cool season crop which can be challenging to produce in a hot tropical environment, where high temperatures may accelerate inflorescence formation and reduce the vegetative period, resulting in an unmarketable crop (Silva et al., 1999). Strategies to successfully grow lettuce in hot climates include planting at high altitudes or in the winter months. For example, in Hawaii the recommendation is to produce Romaine type lettuces at elevations of $150 \mathrm{~m}$ to over $1,000 \mathrm{~m}$ (Valenzuela et al., 1996), and in Florida lettuce production is recommended from August through March (Maynard et al., 1999). However, in Puerto Rico approximately $75 \%$ of the land area is at elevations below $305 \mathrm{~m}$, and virtually all of the estimated 216,102 ha of mechanizable land with slopes of less than $15 \%$ are on the lowland coastal plain (National Academy of Sciences, 1967; Miller and Lugo, 2009). Further- 
more, Puerto Rico is at a lower latitude than Florida, and the average low winter temperature is about $14.8^{\circ} \mathrm{C}$ higher in San Juan than in Miami (NOAA, 2016a).

Among other challenges to organic lettuce cultivation in a tropical environment are pests and diseases, which may be more prevalent than in temperate regions due to year round warm temperatures and high rainfall; therefore, cultivar selection for tolerance to both abiotic and biotic stresses is a critical component of a successful production system. The purpose of this study was to evaluate the performance of eleven lettuce cultivars selected according to their reported heat tolerance, slow bolting, and disease resistance, under an organic management system in a lowland tropical environment, over four seasons and two years. The goal is to be able to produce high quality organic lettuce year round in a tropical location.

\section{MATERIALS AND METHODS}

Organic lettuce cultivar trials were conducted in 2011 (December 2010 transplant date) and 2012 on certified organic land at the Lajas Agricultural Experiment Substation of the University of Puerto Rico in southwestern Puerto Rico (lat. $18^{\circ} 01^{\prime} \mathrm{N}$, long. $67^{\circ} 04^{\prime} \mathrm{W}$, elevation $27 \mathrm{~m}$ ). The soil series is Fraternidad clay (Vertisol) that is very deep, moderately well drained, very slowly permeable and weathered from volcanic rock and limestone (Soil Survey Staff, 2018). During the winter/spring seasons, average monthly precipitation ranges from about 5 $\mathrm{cm}$ in January to over $10 \mathrm{~cm}$ in May. Soil tests revealed high levels of potassium, magnesium, calcium, and copper, with low levels of phosphorous and zinc; soil $\mathrm{pH}$ was 8.2.

Eleven lettuce cultivars were selected for the experiment, based primarily on their reported heat tolerance, delayed bolting, and disease resistance. These included the Romaine types 'Coastal Star', 'Jericho' and 'Parris Island', and the leaf types 'Bergam's Green', 'Black Seeded Simpson', 'Forellenschluss', 'Nevada', 'New Red Fire', 'Queensland', 'Summer Bibb' and 'Thai Green' (Table 1). 'Black Seeded Simpson' is commonly grown for both home garden and commercial lettuce crops in Puerto Rico. To evaluate performance throughout the year, plantings were made in winter (December to February), spring (March to May), summer (June to August) and fall (September to November). Planting times and mean rainfall and temperature for each planting season are listed in Table 2.

For all plantings, seeds were sown in 72-cell plastic trays using a growing mix consisting of 1:1:1 parts by volume of screened composted cow manure, peat moss and perlite. Seedlings were fertilized weekly 
TABLE 1.-Lettuce cultivars selected for the tropical organic cultivar trial at the Lajas Agricultural Experiment Substation, Puerto Rico. Characteristics are those reported by seed suppliers.

\begin{tabular}{|c|c|c|c|}
\hline 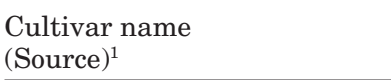 & $\begin{array}{l}\text { Cultivar } \\
\text { type }\end{array}$ & $\begin{array}{l}\text { Days to } \\
\text { harvest }\end{array}$ & $\begin{array}{c}\text { Reported } \\
\text { characteristics }\end{array}$ \\
\hline 'Coastal Star' (J) & Romaine & 57 & HT, CRR \\
\hline ‘Queensland’ (E) & Leaf & \multicolumn{2}{|c|}{ Not specified. HT, BOL } \\
\hline ‘Jericho' (HM) & Romaine & 60 & HT, DT, TB \\
\hline 'Parris Island’ (HM) & Romaine & 55 & LMV, TB \\
\hline 'Forellenschluss' (SE) & Leaf & 55 & HT, BOL \\
\hline ‘Black Seeded Simpson’ (HM) & Leaf & 46 & $\mathrm{HT}, \mathrm{BOL}, \mathrm{TB}, \mathrm{DM}$ \\
\hline 'Nevada' (HM) & Leaf & 55 & $\mathrm{HT}, \mathrm{BOL}, \mathrm{TB}, \mathrm{DM}, \mathrm{BR}, \mathrm{LMV}$ \\
\hline ‘Thai Green’ (SC) & Leaf & 55 & $\mathrm{HT}$ \\
\hline 'Bergam’s Green’ (HM) & Leaf & 55 & HT, BOL, TB, CRR \\
\hline 'New Red Fire' (HM) & Leaf & 55 & $\mathrm{HT}, \mathrm{BOL}, \mathrm{TB}, \mathrm{DM}, \mathrm{BR}$ \\
\hline ‘Summer Bibb’ (PV) & Leaf & 60 & HT, BOL \\
\hline
\end{tabular}

\footnotetext{
${ }^{1}$ Source: Educational Concerns for Hunger Organization (E), High Mowing Seed Company (HM), Johnny's Selected Seeds (J), Peaceful Valley (PV), Seeds of Change (SC).

${ }^{2}$ Cultivar characteristics: $\mathrm{BOL}=$ bolting resistance, $\mathrm{BR}=$ bottom rot resistance, $\mathrm{CRR}=$ corky root rot resistance, $\mathrm{DM}=$ downy mildew resistance, $\mathrm{DT}=$ drought tolerance, $\mathrm{HT}=$ heat tolerance, $\mathrm{LMV}=$ lettuce mosaic virus resistance, $\mathrm{TB}=$ tip burn resistance.
}

by drenching with Dynamega 2-1-1 (BioFlora Systems, Goodyear, AZ) at a rate of $4 \mathrm{~mL} / \mathrm{L}$ and were transplanted to the field at approximately 30 days after seed sowing. BioFlora 6-6-5 granular organic fertilizer (BioFlora Systems, Goodyear, AZ) was incorporated at a rate of $112 \mathrm{~kg} /$ ha $\mathrm{N}$ before transplanting. The experimental design was a randomized complete block with six replications and plots consisting of nine plants. Lettuce plants were transplanted to raised beds $1.5 \mathrm{~m}$ wide, with three rows per bed. Plant spacing was $30.5 \mathrm{~cm}$ and rows were $30.5 \mathrm{~cm}$ apart. For the 2011 fall planting only, we were unable to till the normal field beds due to excessive rain, so the experiment was planted in raised beds in a demonstration garden area using the same soil type, rate of fertilizer application, and plant spacing as in the field. Drip irrigation was supplied as needed and weeding was accomplished by hand hoeing.

The crop experienced little to no pest damage and no pest control products were applied at any time, with the exception of one application of MilStop fungicide (BioWorks Inc., Victor, NY) at a rate of 12 $\mathrm{mL} / \mathrm{L}$ to control leaf spot caused by Cercospora longissima Cooke \&

${ }^{6}$ Company or trade names in this publication are used only to provide specific information. Mention of a company or trade name does not constitute an endorsement by the Agricultural Experiment Station of the University of Puerto Rico, nor is this mention a statement of preference over other equipment or materials. 
J. Agric. Univ. P.R. vol. 102, No. 1-2, 2018

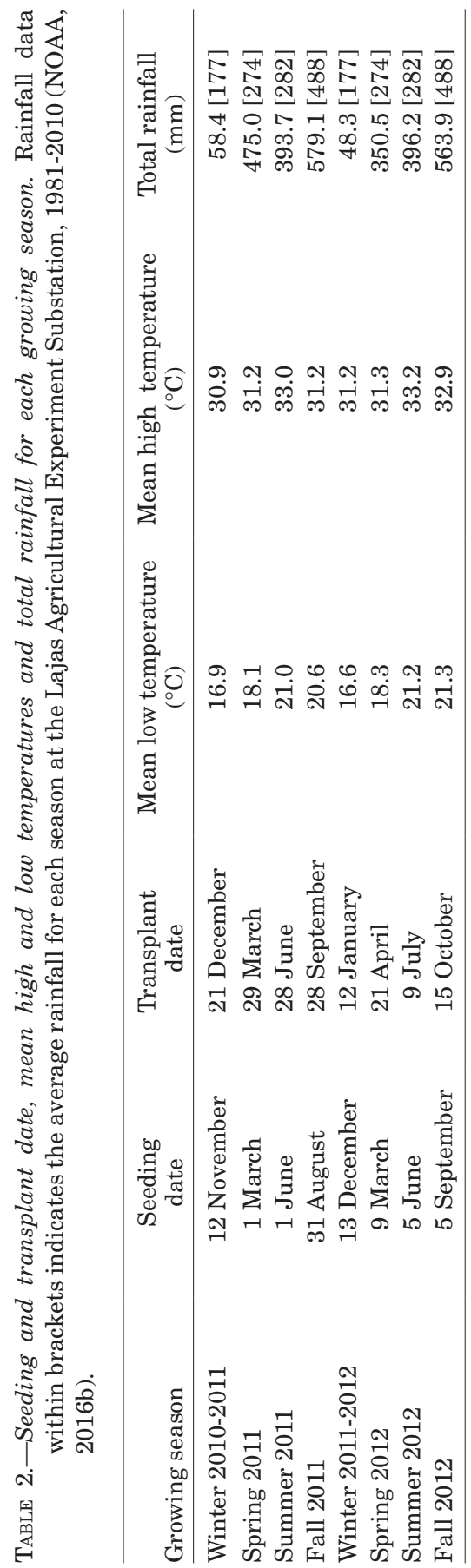


Ellis during the fall 2011 planting. Data were taken for the number of days to bolting, head height (from ground level to the top of the head) and diameter, and harvest weight. Harvest yield was calculated based on a population of 64,556 plants per hectare.

Data were analyzed as a split plot analysis of variance (ANOVA) using InfoStat version 2018, Analysis of Variance (Di Rienzo et al., 2018) with environments (season $\mathrm{x}$ year combinations) as the whole plots and cultivars as the subplots. Environments and cultivars were considered fixed effects. For each variable analyzed, normal Q-Q plots were used to test the assumption of normality of errors, and diagnostic plots of residuals versus predicted values were used to test the assumption of homogeneity of variance (Kozak and Piepho, 2017). Means (among environments, among cultivars within an environment, and among cultivars across all environments) were compared with Fisher's least significant difference using $\mathrm{a}=0.05$.

\section{RESULTS AND DISCUSSION}

There was little deviation from 30-year averages for mean low and high temperatures in each season (data not shown), but there were large deviations for precipitation during the study period (NOAA, 2016b) (Table 2). The 2011 and 2012 winter seasons were abnormally dry, with 67 and $73 \%$ less precipitation than average, while all other seasons had higher than average rainfall, ranging from $15.6 \%$ more rain in fall 2012 to $73.4 \%$ more than normal in spring 2011.

In the data analysis the four growing seasons in each of two years were treated as eight environments. Q-Q plot indicated that errors for some variables deviated from normality, but distributions for all variables were uni-modal and symmetric. In general, diagnostic plots of residuals versus predicted values suggested that assumptions of homogeneity of variance were met. The plot for plant height indicated some degree of heterogeneity, with variances being smaller for very short or very tall cultivars. Dixon et al. (2018) suggest that the assumption of homogeneity of variance can be relaxed in many cases, especially when sample size is adequate, which was the case in this study. There was a highly significant $(\mathrm{P}<0.0001)$ environment $\mathrm{x}$ cultivar interaction for each of the five traits studied. Therefore, we focused on: (1) differences among seasons in each of the two years when averaged over cultivars (the season $\mathrm{x}$ year interaction) and (2) differences among cultivars in each season of the two years of the experiment (the cultivar $\mathrm{x}$ environment interaction).

Bolting or premature flowering reduces the harvest period and decreases lettuce yield and quality. The overall mean for days from 
transplanting to flowering was 37.8 in 2011 and 35.1 in 2012, but relative differences among cultivars varied greatly depending on the season (Table 3). With one exception (2012 for 'Black Seeded Simpson'), all cultivars bolted later in the winter than in other seasons, although seasonal differences for particular cultivars were not always significant. There was a slight trend for flowering to be earliest in the summer, but in many cultivars bolting occurred equally early in the spring or fall as in the summer. The fastest bolting cultivars were 'Black Seeded Simpson' (24.6 days), 'Forellenschluss' (27.7 d) and 'Thai Green' (30.5 d); these cultivars showed little or no seasonal differences in days to flowering. 'Nevada' (50.2 d), 'Queensland' (46.1 d) and 'New Red Fire' ( $46.3 \mathrm{~d})$ consistently were the last cultivars to bolt in all seasons. Slow bolting in a tropical environment provides a longer harvest window and more flexibility for the grower. 'Nevada', 'Queensland' and 'New Red Fire' had extended harvest periods of 25.6, 21.5 and $21.7 \mathrm{~d}$, respectively, compared to the traditional cultivar 'Black Seeded Simpson'.

Although there were a few exceptions ('Nevada' and 'Parris Island'), cultivars generally grew taller in the winter or spring season than in summer or fall (Table 4). No cultivar was consistently among the tallest in every season. However, 'Coastal Star', 'Black Seeded Simpson' and 'Parris Island' were among the tallest cultivars in at least four of the eight environments. 'Summer Bibb', 'New Red Fire' and 'Nevada' were among the shortest cultivars in nearly every season of both years.

In both years and for all cultivars, plant diameter was greatest in either the winter or spring planting, although differences between winter and spring versus summer and fall were not significant for all cultivars (Table 5). 'Queensland', 'New Red Fire' and 'Bergam's Green' tended to be in the group of large diameter plants. 'Summer Bibb' was among the smallest diameter cultivars in every season of both years. 'Black Seeded Simpson' and 'Forellenschluss' also tended to produce small diameter plants.

Head weight and harvest yield averaged over cultivars were almost always the greatest in winter or spring, no matter the year (Tables 6 and 7). Fall plantings generally resulted in plants with the smallest heads and lowest yields while summer plantings were intermediate in head weight and yield. 'Queensland' had both the largest head weight and highest yield in all seasons of both years, although other cultivars were sometimes not significantly different from this one. Other cultivars that produced large head weight and high yield in most environments were 'Bergam's Green' and 'Jericho'. 'Black Seeded Simpson', 'Summer Bibb', 'Thai Green' and 'Forellenschluss' were among the poorest cultivars in terms of head weight and harvest yield. 


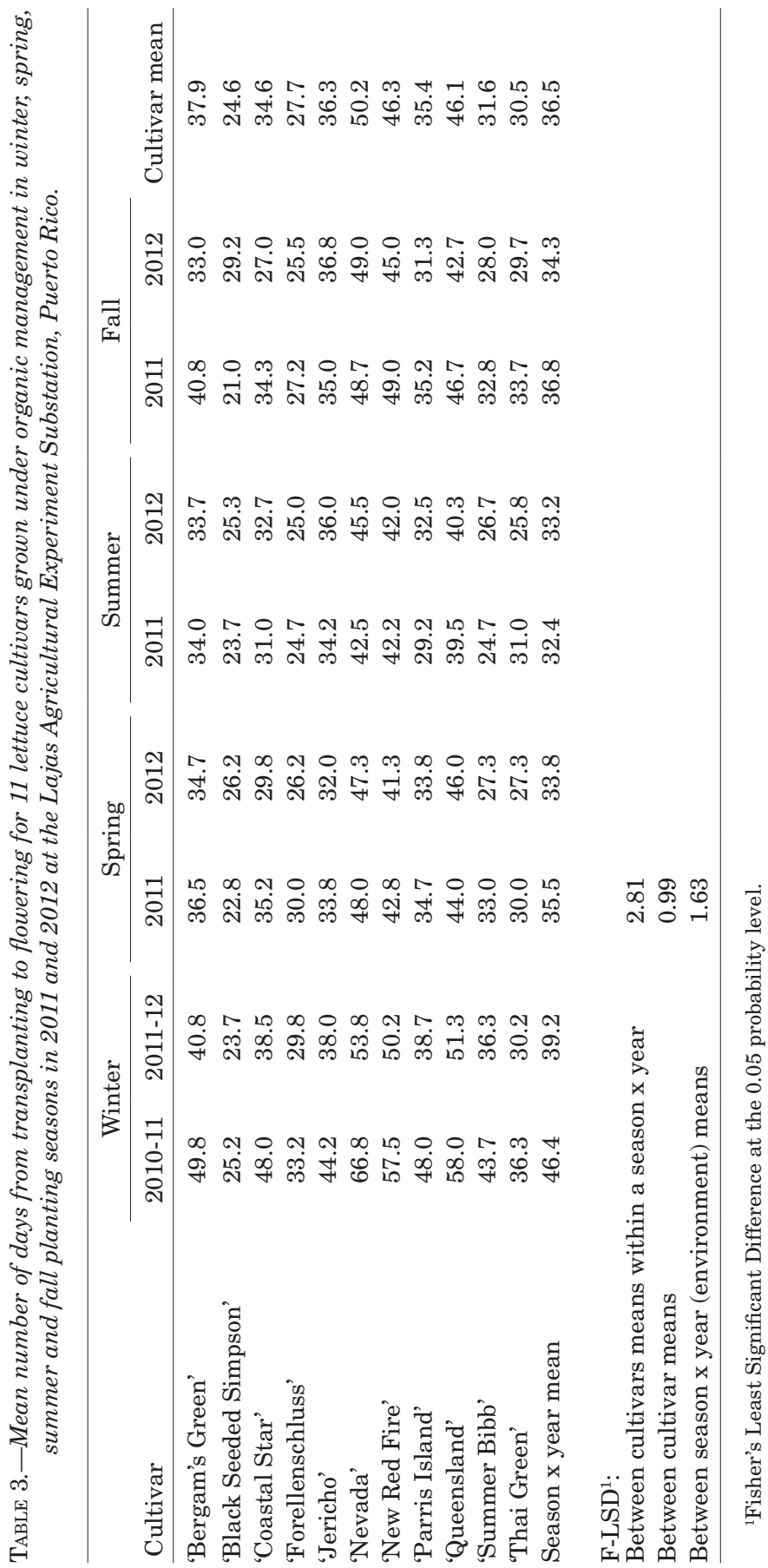


J. Agric. Univ. P.R. vol. 102, No. 1-2, 2018

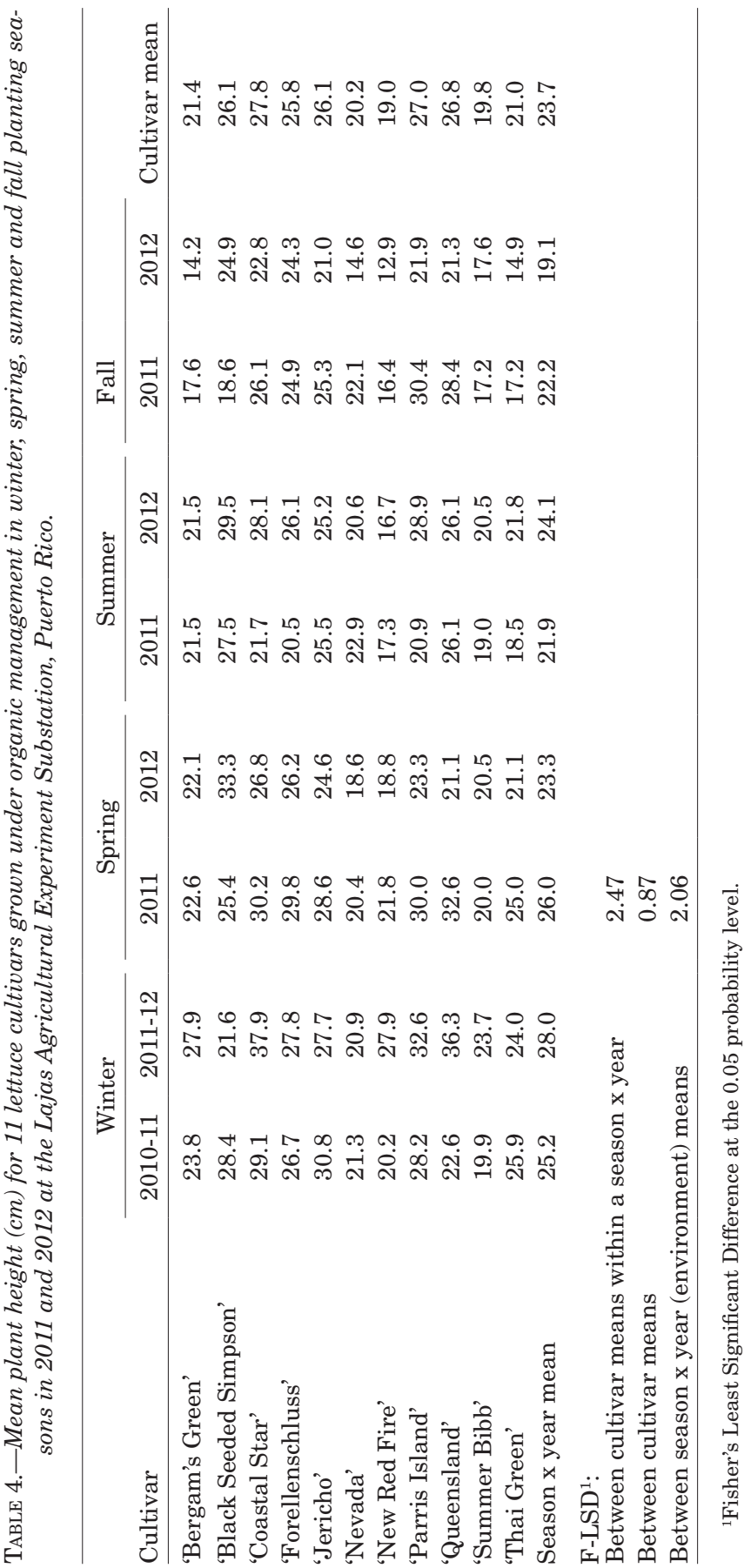




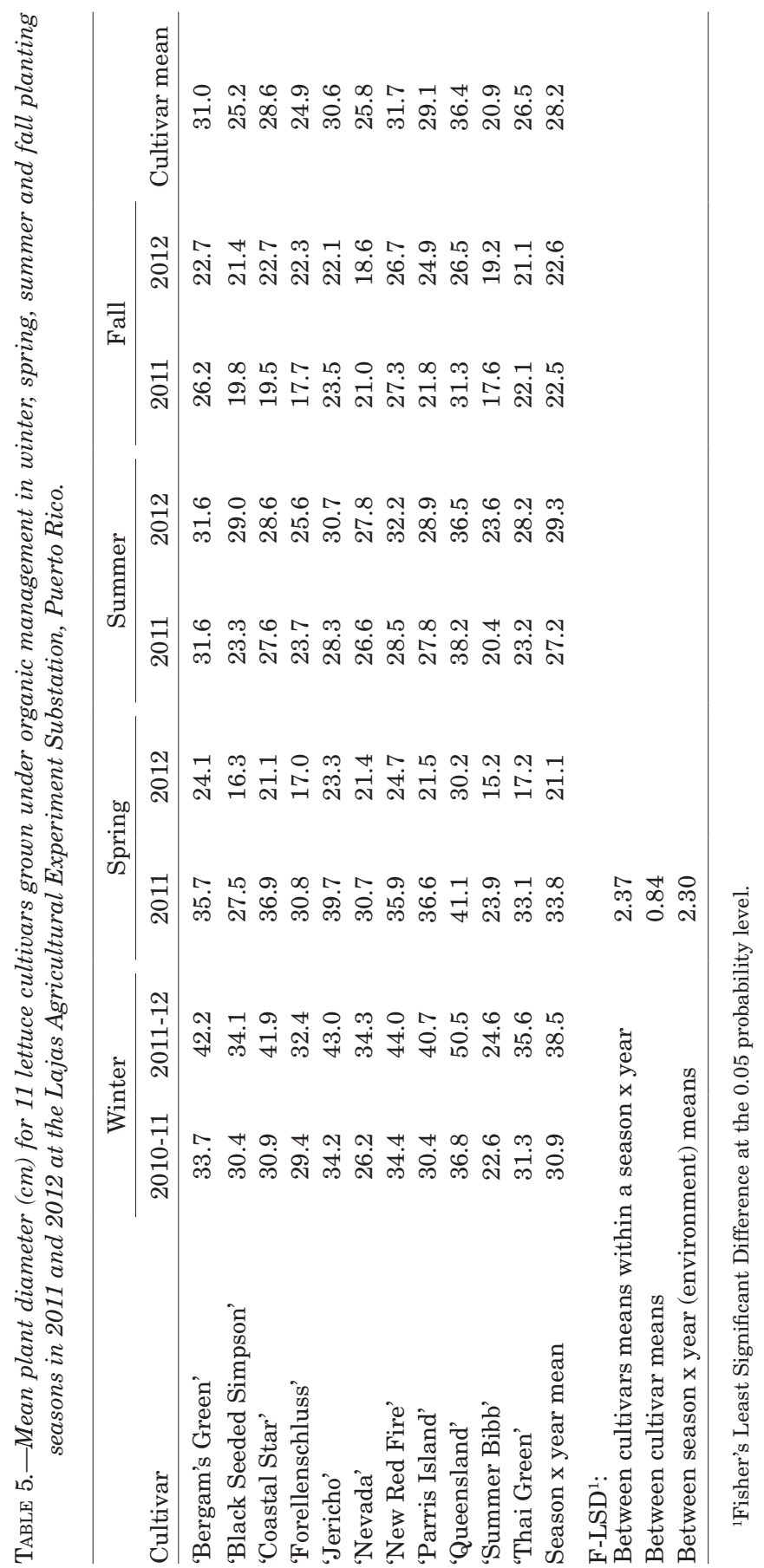


J. Agric. Univ. P.R. vol. 102, No. 1-2, 2018

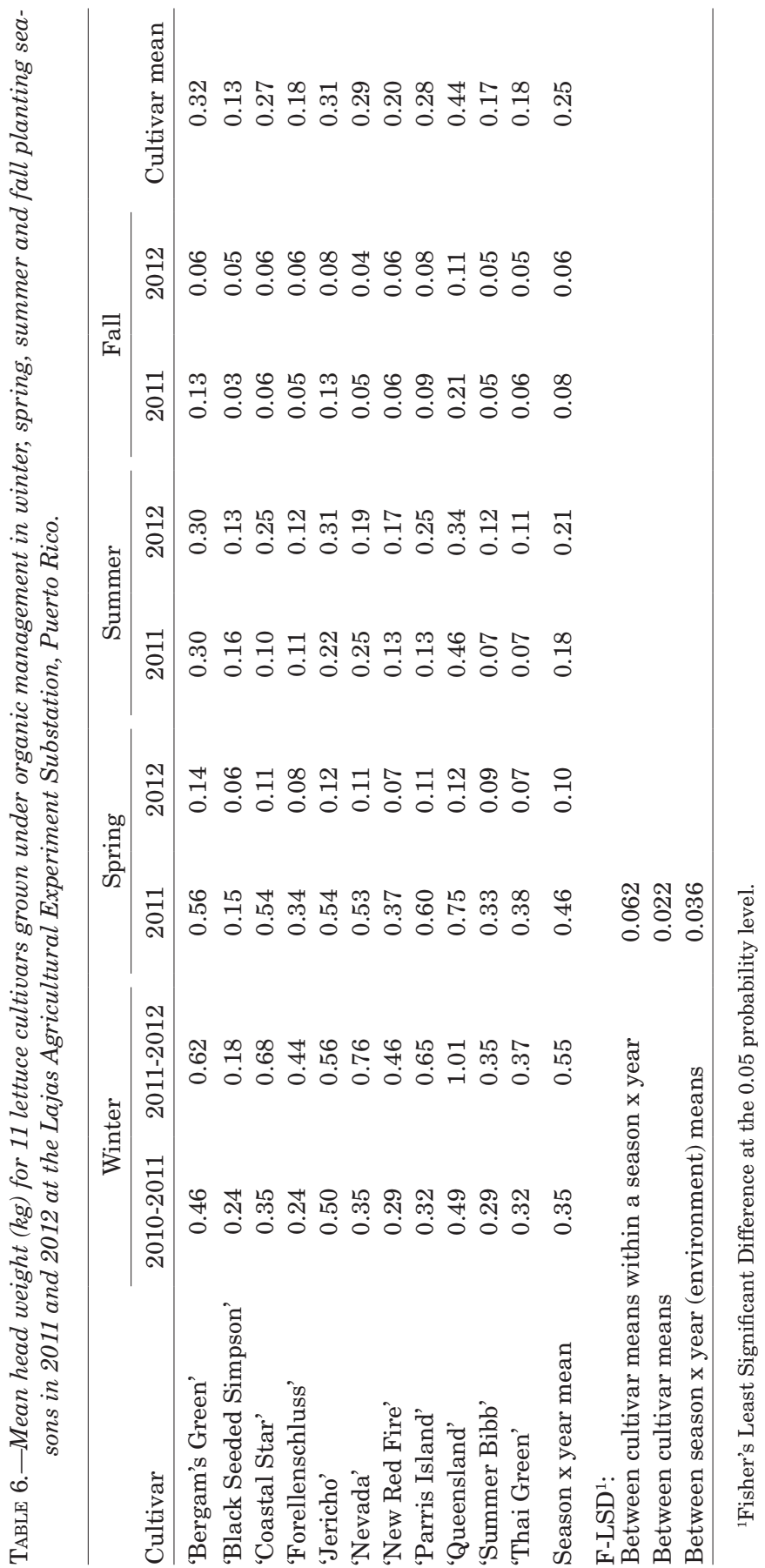




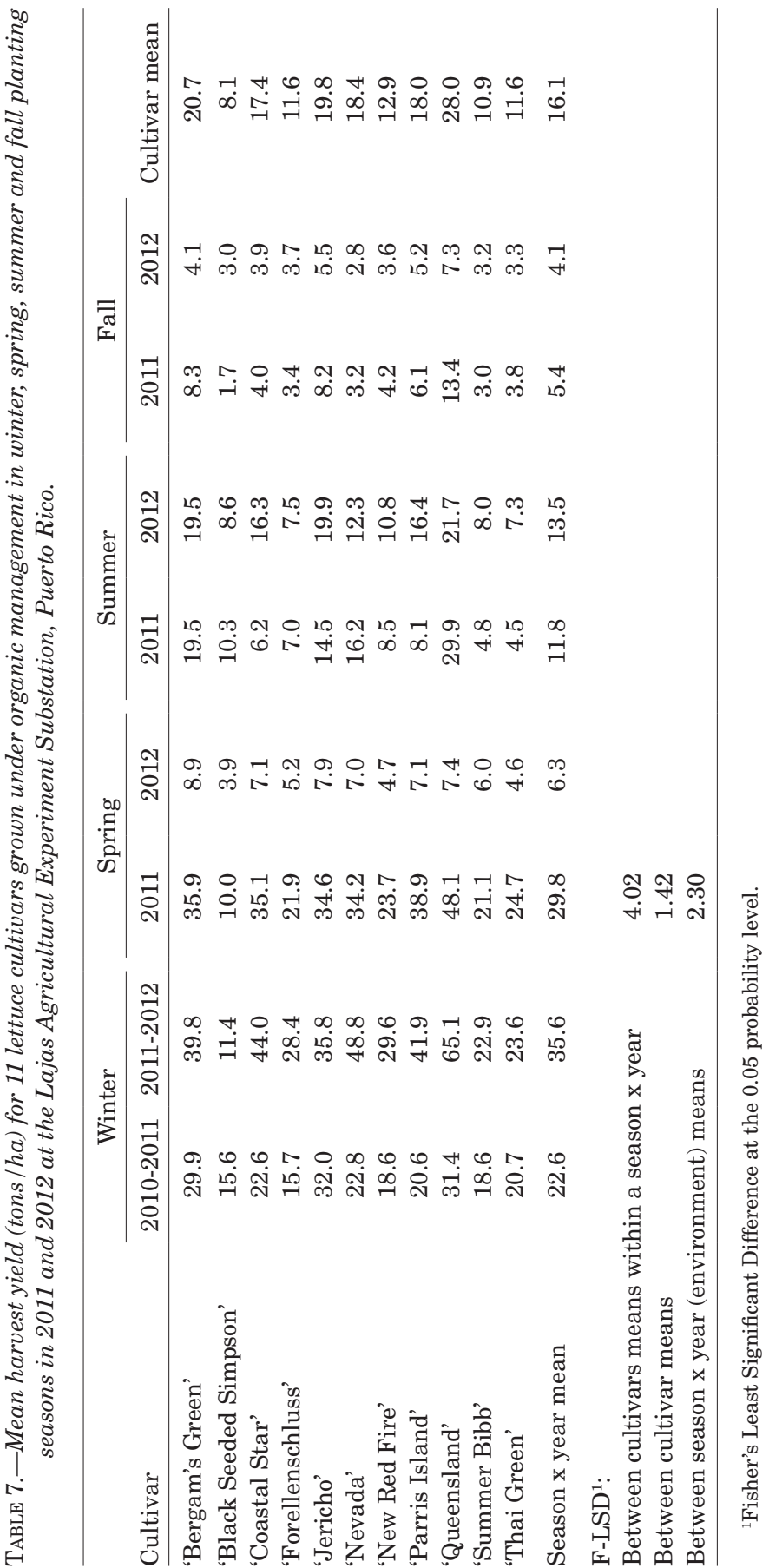


Our results are in agreement with Hartmann et al. (1981), who reported a significant negative correlation $(\mathrm{r}=-0.543, \mathrm{p}<0.01)$ between lettuce yields and total rainfall during the growing season. Our yields of organic lettuce, especially in winter and spring seasons, compared favorably with lettuce yields in other hot environments and with organic lettuce. Lu and Sui (2012) reported yields of 12.5 to $23 \mathrm{t} / \mathrm{ha}$ for conventionally grown iceberg lettuce and 16.5 to $28.2 \mathrm{t} / \mathrm{ha}$ for conventional romaine lettuce grown in the winter season in southern Florida. In Hawaii, Valenzuela et al. (2009) observed yields of 3.1 to $31.4 \mathrm{t} / \mathrm{ha}$, with a mean of $19.1 \mathrm{t} / \mathrm{ha}$, for 23 romaine lettuce cultivars grown in the winter season. In a temperate climate, Isik et al. (2009) reported yields of organic leaf lettuce of 17.8 to $22.1 \mathrm{t} / \mathrm{ha}$.

Cultivars could be grouped into two classes, high and low yielders, corresponding to high and low head weight groups listed previously. 'Queensland' was the highest yielder in every season and yielded over two times the average of all the genotypes in the adverse summer and fall seasons, making it a valuable cultivar for year round production in the tropics. 'Bergam's Green', 'Jericho' and 'Parris Island' also performed fairly well throughout the year. 'Nevada', 'Coastal Star' and 'New Red Fire' performed well in winter, spring and summer, but not in the more adverse fall season. 'Thai Green' did not perform well in summer or fall seasons; it also bolts fairly quickly and is not recommended for Puerto Rico. 'Summer Bibb' is a small headed lettuce that did not perform well in summer or fall seasons, but it could be planted in winter or spring, and at a higher plant density, which would improve harvest yield. 'Black Seeded Simpson', which is commonly grown in Puerto Rico and known as "lechuga del país" or local lettuce, had the lowest yields, the smallest head weight, and was quickest to bolt. Therefore it is not recommended for production as spaced, transplanted head lettuce. An alternative would be to broadcast seed of this cultivar in beds since it is quick growing and fast to mature.

Our results show that organic lettuce can be produced year round in the field in Puerto Rico with appropriate cultivars. 'Queensland', 'Bergam's Green', 'Jericho' and 'Parris Island' are recommended for year round production, although yields can be expected to be higher in cooler, dryer weather. Shading and rain protection could help to improve yields in the hot, rainy summer and fall seasons.

\section{LITERATURE CITED}

Di Rienzo J.A., F. Casanoves, M.G. Balzarini, L. Gonzalez, M. Tablada and C.W. Robledo, 2018. InfoStat versión 2018. Grupo InfoStat, FCA, Universidad Nacional de Córdoba, Argentina. URL http://www.infostat.com.ar 
Dixon, P. M., K. J. Moore and E. van Santen, 2018. Chapter 8: The analysis of combined experiments. In: B. Glaz and K.M. Yeater (eds), Applied statistics in agricultural, biological and environmental sciences. American Society of Agronomy-Crop Science Society of America-Soil Science Society of America, Madison, Wisconsin. Doi:10.2134/appliedstatistics.2016.0004.

FAO (Food and Agriculture Organization), 2015. FAOSTAT lettuce and chicory production 2012. http://faostat.fao.org/site/567/DesktopDefault.aspx?PageID=567 (Viewed 17 July 2015).

Hartmann, R. W., R. J. Ito, K. Kubojiri, R.R. Romanowski and B. A. Kratky, 1981. Volcano head lettuce trials, 1963-1975. Hawaii Agric. Exp. Sta. Res. Rep. 170.

Isik, D., E. Kaya, M. Ngouajio and H. Mennan, 2009. Summer cover crops for weed management and yield improvement in organic lettuce (Lactuca sativa) production. Phytoparasitica 37: 193-203.

Kozak, M. and H.-P. Piepho, 2017. What's normal anyway? Residual plots are more telling than significance tests when checking anova assumptions. J. Agronomy Crop Sci. 204(1): 86-98. https://onlinelibrary.wiley.com/doi/full/10.1111/jac.12220 (Viewed 10 September 2018).

Lu, H. and D. Sui, 2012. Field performance of lettuce cultivars used in southern Florida. Proc. Fla. State Hort. Soc. 125: 137-138.

Maynard, D. N., G. J. Hochmuth, C. S. Vavrina, W. M. Stall, T. A. Kucharek, P. A. Stansly, T. G. Taylor, S. A. Smith and A. G. Smajstrla, 1999. Lettuce, endive, escarole production in Florida. Publication HS 728, University of Florida. 10 pp.

Miller, G. L. and A. E. Lugo, 2009. Guide to the ecological systems of Puerto Rico. Gen. Tech. Rep. IITF-GTR-35. San Juan, PR: U.S. Department of Agriculture, Forest Service, International Institute of Tropical Forestry. $437 \mathrm{pp}$.

National Academy of Sciences, 1967. Science and technology in support of the Puerto Rican economy. National Academy of Sciences, National Research Council, Washington, D.C.

NOAA (National Oceanic and Atmospheric Administration), 2016a. National Weather Service Southern Region Headquarters. http://www.srh.noaa.gov/ (Viewed 10 May 2016).

NOAA (National Oceanic and Atmospheric Administration), 2016b. National Weather Service Weather Forecast Office. http://www.srh.noaa.gov/sju/?n=climo_lajas\#LajasAES (Viewed 10 May 2016).

P.R. Department of Agriculture, 2015. Ingreso bruto de la agricultura de Puerto Rico. http://www2.pr.gov/agencias/Agricultura/estad\%C3\%ADsticas/Documents/ Estad\%C3\%ADsticas/IBA\%202009-2014\%20final.pdf (Viewed 4 August 2015).

Silva, E. C., W. R. Maluf, N. R. Leal and L. A. A. Gomes, 1999. Inheritance of bolting tendency in lettuce Lactuca sativa L. Euphytica 109: 1-7.

Soil Survey Staff, 2018. Web Soil Survey. Natural Resources Conservation Service, United States Department of Agriculture. https://websoilsurvey.sc.egov.usda.gov/ (Viewed 6 September 2018).

U.S. Census Bureau, 2013. U.S. trade with Puerto Rico and U.S. possessions. U.S. Census Bureau, Washington, D.C. https:/census.gov/content/dam/Census/library/publications/2014/econ/ft895-13.pdf (Viewed 11 September 2018).

Valenzuela, H., T. Goo and S. Migita, 2009. Romaine lettuce variety trials, 2009. UH Poamoho Experiment Station, University of Hawaii at Manoa. 12 pp.

Valenzuela, H. R., B. Kratky and J. Cho, 1996. Lettuce production guidelines for Hawaii. Research Extension Series 164, University of Hawaii at Manoa. 20 pp. 